\title{
Proliferative and Invasive Effects of Progesterone-Induced Blocking Factor in Human Glioblastoma Cells
}

\author{
Araceli Gutiérrez-Rodríguez, ${ }^{1}$ Valeria Hansberg-Pastor, ${ }^{2}$ and Ignacio Camacho-Arroyo ${ }^{1}$ \\ ${ }^{1}$ Unidad de Investigación en Reproducción Humana, Instituto Nacional de Perinatología-Facultad de Química, \\ Universidad Nacional Autónoma de México (UNAM), Ciudad Universitaria, Coyoacán, 04510 Ciudad de México, Mexico \\ ${ }^{2}$ Facultad de Química, Departamento de Biología, UNAM, Ciudad Universitaria, Coyoacán, 04510 Ciudad de México, Mexico
}

Correspondence should be addressed to Ignacio Camacho-Arroyo; camachoarroyo@gmail.com

Received 8 August 2016; Revised 24 November 2016; Accepted 15 December 2016; Published 12 January 2017

Academic Editor: Jens Schittenhelm

Copyright (c) 2017 Araceli Gutiérrez-Rodríguez et al. This is an open access article distributed under the Creative Commons Attribution License, which permits unrestricted use, distribution, and reproduction in any medium, provided the original work is properly cited.

\begin{abstract}
Progesterone-induced blocking factor (PIBF) is a progesterone $\left(\mathrm{P}_{4}\right)$ regulated protein expressed in different types of high proliferative cells including astrocytomas, the most frequent and aggressive brain tumors. It has been shown that PIBF increases the number of human astrocytoma cells. In this work, we evaluated PIBF regulation by $\mathrm{P}_{4}$ and the effects of PIBF on proliferation, migration, and invasion of U87 and U251 cells, both derived from human glioblastomas. PIBF mRNA expression was upregulated by $\mathrm{P}_{4}(10 \mathrm{nM})$ from 12 to $24 \mathrm{~h}$. Glioblastoma cells expressed two PIBF isoforms, 90 and $57 \mathrm{kDa}$. The content of the shorter isoform was increased by $\mathrm{P}_{4}$ at $24 \mathrm{~h}$, while progesterone receptor antagonist RU486 $(10 \mu \mathrm{M})$ blocked this effect. PIBF $(100 \mathrm{ng} / \mathrm{mL}) \mathrm{increased}$ the number of U87 cells on days 4 and 5 of treatment and induced cell proliferation on day 4 . Wound-healing assays showed that PIBF increased the migration of U87 (12-48 h) and U251 ( 24 and $48 \mathrm{~h})$ cells. Transwell invasion assays showed that PIBF augmented the number of invasive cells in both cell lines at $24 \mathrm{~h}$. These data suggest that PIBF promotes proliferation, migration, and invasion of human glioblastoma cells.
\end{abstract}

\section{Introduction}

Progesterone $\left(\mathrm{P}_{4}\right)$ is a cholesterol-derived steroid hormone that is synthesized by the adrenal glands, gonads, and the central nervous system (CNS) [1]. $\mathrm{P}_{4}$ participates in the growth of several types of cancer through the activation of its intracellular receptor (PR), which is a ligand-activated transcription factor $[2,3] . \mathrm{P}_{4}$ promotes the growth, migration, and invasion of human astrocytoma cells lines such as U373 (grade III), U87, and D54 (both grade IV or glioblastomas) [4-6]. In these cell lines, $\mathrm{P}_{4}$ effects are mostly mediated by $\mathrm{PR}$, given that the treatment with the receptor antagonist, mifepristone (RU486), almost completely blocks hormone effects. One of the known PR target genes is the progesteroneinduced blocking factor (PIBF) that was initially discovered in maternal lymphocytes where it functions as an immunomodulatory factor $[7,8]$.
Several PIBF isoforms are produced by alternative splicing; the most studied ones are the isoforms of $34,57,67$, and $90 \mathrm{kDa}$ [9-11]. The latter is the most abundant isoform expressed in most cells, which has been shown to be associated with the centrosome, suggesting a participation in cell cycle regulation [9]. The shorter PIBF isoforms present a tissue-specific expression and have been located in the intra- and extracellular compartments $[9,10]$. These short isoforms have been proposed as ligands of the PIBF receptor/interleukin 4 receptor $\alpha$ (PIBF-R/IL- $4 \mathrm{R} \alpha$ ) heterocomplex that activates diverse proliferative signaling pathways $[12,13]$. The most studied pathway is the IL-4R/JAK1/STAT6 [10, 12, 14], associated with the differentiation of Th2 cells, to produce a cytokine specific pattern [15], and with tumor cell growth [16]. Besides, data from our laboratory have demonstrated that PIBF is released to the extracellular compartment and increases the number of U373 cells through the activation 
of the IL-4R/JAK1/STAT6 pathway [10]. PIBF expression is induced by $\mathrm{P}_{4}$ and its production is a common feature during pregnancy $[8,14]$. However, it is also synthesized by high proliferative cells such as the trophoblast, mesenchymal stem cells, and tumor cells $[9,14,17]$.

PIBF has been associated with cancer due to its proximity to the susceptibility genes of breast cancer in chromosome 13 [9]. Several reports show that PIBF is overexpressed in biopsies of uterus, breast, stomach, and brain cancer [9, 18]. Besides, PIBF is highly expressed in several cancer cell lines derived from astrocytomas (U373) [10], cervix adenocarcinoma (HeLa), chronic myeloid leukemia (K562), ovary adenocarcinoma (OVCAR-3), and breast adenocarcinomas (T47D, SK-BR3, and MCF-7) [9]. In fact, high PIBF concentrations in urine $(1000 \mathrm{ng} / \mathrm{mL})$ are observed in patients with malignant tumors, which are almost fourfold higher than those observed during pregnancy $(\sim 270 \mathrm{ng} / \mathrm{mL})$ $[12,14]$. However, Check et al., 2015, reported that PIBF serum concentrations are not higher in patients with gynecological [19] or breast cancer compared to women with benign tumors [20, 21], possibly due to a mutation of BRCA1 gene that induces the degradation of PR by the proteasome $26 \mathrm{~S}$ [22]. In these studies, an evaluation of intracytoplasmic PIBF concentrations to elucidate these different findings is suggested.

PIBF expression has been described in astrocytomas [10, 18] which are classified by the World Health Organization (WHO) into four grades (I-IV). Astrocytomas grade IV, also known as glioblastomas, represent the highest evolution grade and also the most frequent malignant brain tumors in humans [23]. Glioblastomas ability to invade several areas of the brain and their short-term recurrence causes the highest rate of death by brain tumors [24]. It has been reported that $\mathrm{P}_{4}$ is implicated in the invasive potential of glioblastomas [4]; however, the mechanisms involved in this effect are not completely understood. Interestingly, in a case report, the administration of RU486 resulted in a palliative effect and even extended the patient's life [25]. Glioblastomas are also highly immunosuppressive [26], probably through the secretion of immunomodulatory factors such as TGF$\beta$ or PIBF $[27,28]$. Interestingly, the latter causes a marked diminution of Th1/Th2 cells ratio during pregnancy $[15,29]$, leading to an immunosuppressive state, which may provide glioma cells with a mechanism of evasion from organism immune system and facilitate tumor progression [30]. Given that PIBF is induced by $\mathrm{P}_{4}$ and modulates different pathways involved in cell growth and inflammation, the aim of this study was to investigate the role of PIBF in cell proliferation, migration, and invasion of U87 and U251 cells derived from human glioblastomas.

\section{Materials and Methods}

2.1. Cell Culture. U87 and U251 (ATCC, VA, USA) cells derived from human glioblastomas were cultured in Dulbecco's modified eagle medium (DMEM) with phenol red, supplemented with fetal bovine serum (FBS) (10\%), pyruvate $(1 \mathrm{mM})$, glutamine $(2 \mathrm{mM})$, and nonessential amino acids
(0.1 nM) (Biowest, Nuaillé, FRA); the culture was maintained at $37^{\circ} \mathrm{C}$, under $95 \%$ humidity $/ 5 \% \mathrm{CO}_{2}$ atmosphere. Cells were grown until reaching a $70-80 \%$ confluence.

2.2. Treatments. U87 and U251 cells were grown in phenol red-free DMEM medium (In Vitro S.A., CDMX, MEX) supplemented with FBS (10\%) without hormones 24 hours before the following treatments: vehicle (cyclodextrin $0.02 \%$ ), $\mathrm{P}_{4}$ coupled to cyclodextrin $(10 \mathrm{nM}), \mathrm{PR}$ antagonist RU486 $(10 \mu \mathrm{M})$, and the combined treatment of $\mathrm{P}_{4}$ plus RU486. Recombinant PIBF (100 and $200 \mathrm{ng} / \mathrm{mL}$ ) (Abnova, TP, TWN) was used for treating cells in the cell counting, proliferation, wound-healing, and transwell assays. Phenol red and hormone-free DMEM was used as the vehicle in these experiments. Recombinant PIBF shows isoforms with approximate molecular weights of 95,60 , and $40 \mathrm{kDa}$ according to the manufacturer's specifications.

2.3. Total RNA Extraction and RT-PCR. To determine the effect of $\mathrm{P}_{4}$ on $\mathrm{PIBF}$ gene expression, $5 \times 10^{5}$ cells were grown as described in the "Cell Culture" section and treated for 6,12 , and $24 \mathrm{~h}$. Total RNA was isolated from U87 cells by the method based on guanidine isothiocyanate/phenol/chloroform extraction according to the TRIzol reagent manufacturer's protocol (Invitrogen, CA, USA). Isolated RNA was quantified using the spectrophotometer Nanodrop-2000 (Thermo Scientific, MA, USA) at $260 \mathrm{~nm} .1 \mu \mathrm{g}$ of total RNA was used to synthesize the first-strand CDNA with the MMLV reverse transcriptase (Thermo Scientific, MA, USA) following the manufacturer's instructions. $2 \mu \mathrm{L}$ of synthesized cDNA was used to amplify PIBF and the internal control $18 \mathrm{~S}$ ribosomal RNA (rRNA) with the following specific primers: $5^{\prime}$-GACAGAGCCAATTCGCTATTAAACCAGACTCAACAGC- $3^{\prime}$ in the sense primer and $5^{\prime}$-GCTGAGTACACGATTAAGCTGAATTTTGTTTTCCATCAG- $3^{\prime}$ in the antisense for PIBF, and for $18 \mathrm{~S}$ amplification the sequences were $5^{\prime}$-CGCGGTTCTATTTTGTTGGT- $3^{\prime}$ in the sense and $5^{\prime}$ AGTCGGCATCGTTTATGGTC- $3^{\prime}$ in the antisense (SigmaAldrich, MO, USA). Negative controls without cDNA and with nonretrotranscribed RNA were included in all experiments. The PCR reaction was performed as follows: an initial PCR activation step at $94^{\circ} \mathrm{C}$ (5 min), 25 cycles of denaturation at $94^{\circ} \mathrm{C}(30 \mathrm{~s})$, annealing at $68^{\circ} \mathrm{C}(30 \mathrm{~s})$, and elongation at $72^{\circ} \mathrm{C}$ (30 s). A final extension cycle was performed at $72^{\circ} \mathrm{C}(5 \mathrm{~min})$. The PCR products were separated by electrophoresis on a $1.5 \%$ agarose gel at $70 \mathrm{~V}$ for $120 \mathrm{~min}$ and stained with GelRed ${ }^{\mathrm{TM}}$ (Biotium, CA, USA). The gel image was captured under a UV transilluminator and analyzed for band densitometry using the ImageJ software (National Institute of Health, WA, USA). PIBF expression level was normalized to that of the internal control 18S rRNA.

2.4. Western Blotting. To determine the effect of $\mathrm{P}_{4}$ on PIBF protein content in the U87 cell line, $5 \times 10^{5}$ cells were seeded in 6-well plates and treated for 12 and $24 \mathrm{~h}$ as described in the "Treatments" section. Total proteins were extracted with RIPA lysis buffer (150 nM NaCl, $50 \mathrm{nM}$ Tris- $\mathrm{HCl}, 1 \mathrm{mM}$ EDTA, $1 \%$ Triton, and $0.1 \%$ SDS) and quantified using the 
spectrophotometer Nanodrop-2000 (Thermo Scientific, MA, USA) at $280 \mathrm{~nm} .70 \mu \mathrm{g}$ of total lysate protein was separated on $7.5 \%$ SDS-PAGE at $70 \mathrm{~V}$ for $2 \mathrm{~h}$. The proteins were transferred to nitrocellulose membranes (Millipore, MA, USA) at $60 \mathrm{~mA}$ for $2 \mathrm{~h}$ in semidry conditions. After blocking with $3 \%$ fat-free milk and $2 \%$ bovine serum albumin (BSA) at $4^{\circ} \mathrm{C}$ overnight, the membrane was incubated with an antibody against PIBF $(1 \mu \mathrm{g} / \mathrm{mL}$, sc-99129, Santa Cruz Biotechnology, TX, USA) at $4^{\circ} \mathrm{C}$ overnight. Blots were then incubated with an anti-rabbit secondary antibody conjugated to horseradish peroxidase $(0.2 \mu \mathrm{g} / \mathrm{mL}$, sc-2004, Santa Cruz Biotechnology, TX, USA) for $45 \mathrm{~min}$ at room temperature. In order to correct the differences in the amount of total protein loaded, membranes were incubated with glycine $(0.1 \mathrm{M}, \mathrm{pH} 2.5,0.5 \% \mathrm{SDS})$ for $45 \mathrm{~min}$ at room temperature and afterwards with the $\alpha$ tubulin primary antibody $(0.5 \mu \mathrm{g} / \mathrm{mL}, \mathrm{sc}-5286$, Santa Cruz Biotechnology, TX, USA) at $4^{\circ} \mathrm{C}$ overnight. Blots were incubated with an anti-mouse secondary antibody conjugated to horseradish peroxidase $(0.2 \mu \mathrm{g} / \mathrm{mL}, \mathrm{sc}-2005$, Santa Cruz Biotechnology, TX, USA) for $45 \mathrm{~min}$. Chemiluminescence signals were detected exposing the membranes to Kodak Biomax Light Films (Sigma-Aldrich, MO, USA) using the peroxidase substrate SuperSignal West Femto Maximum Sensitivity (Thermo Scientific, MA, USA). Blot images were captured using a Canon digital camera and the bands intensities were quantified with the ImageJ software (National Institute of Health, WA, USA).

2.5. siRNA Transfection. To determine the specificity of PIBF bands obtained by Western Blot, PIBF silencing was performed as follows: $1 \times 10^{5} \mathrm{U} 87$ cells were seeded in 6 wells in DMEM without antibiotics, and $24 \mathrm{~h}$ later the medium was replaced with phenol red and antibiotics-free DMEM, with a control siRNA that has no specific mRNA target sequence, and a PIBF siRNA (75 nM) (Santa Cruz Biotechnology, TX, USA), using the transfection reagent Lipofectamine RNAiMAX (Thermo Scientific, MA, USA). Cells were harvested $48 \mathrm{~h}$ after the transfection and a Western Blot analysis was performed as described in the "Western Blotting" section.

2.6. Cell Counting. $1 \times 10^{4}$ U87 cells were seeded in 24 -well plates and grown for $24 \mathrm{~h}$; cells were treated for 5 days as described in "Treatments" section and harvested from incubation each day. The trypan blue dye exclusion assay was used to test the effect of PIBF on cell growth and viability, using a Neubauer chamber and an inverted microscope CKX41 (Olympus, TYO, JPN) at 40x magnification.

2.7. Cell Proliferation Assay. 5-bromo-2'-deoxy-uridine (Br$\mathrm{dU}$ ) incorporation assay was used to test the proliferative effect of PIBF. $4 \times 10^{3}$ U87 cells were seeded in chambered cell culture slides and maintained as described in the "Cell Culture" section. After $24 \mathrm{~h}$, the medium was replaced for phenol red and hormone-free DMEM medium. Cells were treated for 4 days as described in "Treatments" section. After treatments, the bromo- $2^{\prime}$-deoxy-uridine Labeling and Detection Kit I (Roche, BW, DE) was used according to the manufacturer's protocol. Hoechst 33342 Fluorescent Dye (Thermo Scientific, MA, USA) was used to stain the DNA. The fluorescence signal was observed at dual-wave lengths of 486 and 515-565 $\mathrm{nm}$ in the fluorescence microscope Olympus Bx43F (Olympus, TYO, JPN). The number of cells with BrdU incorporation was obtained using the ImageJ software (National Institute of Health, WA, USA) and the percentage of cells positive for BrdU was calculated considering the total number of cells stained with Hoechst.

2.8. Migration Assay. The wound-healing assay was used to examine the effect of PIBF on glioblastoma cell migration. $3 \times 10^{5}$ U87 cells and $2 \times 10^{5}$ U251 cells were seeded in sixwell plates and grown until reaching a $70-80 \%$ confluence; then the medium was changed for phenol red-free DMEM medium supplemented with fetal bovine serum (10\%) without hormones. $24 \mathrm{~h}$ later, when the monolayer was absolutely confluent, two parallel scratches by well were made with a $200 \mu \mathrm{L}$ pipet tip. The detached cells were washed by aspiration. Cells were incubated with DNA synthesis inhibitor cytosine $\beta$-D-arabinofuranoside hydrochloride $(10 \mu \mathrm{M}$, AraC; Sigma-Aldrich, MO, USA) for $1 \mathrm{~h}$ prior to PIBF treatments to avoid cell proliferation. Images of the scratch area were captured with an Infinity 1-2C camera (Lumenera, ON, CAN) attached to an inverted microscope CKX41 (Olympus, TYO, JPN) at $40 \mathrm{x}$ magnification at $0,3,6,12,24$, and $48 \mathrm{~h}$. At $24 \mathrm{~h}$ medium, treatments, and Ara-C were replaced. Three random fields were selected to count the number of cells that migrated in the scratch area using the ImageJ software (National Institute of Health, WA, USA).

2.9. Invasion Assay. To evaluate the effect of PIBF on cell invasion, transwell invasion assays were performed. $1 \mathrm{~mL}$ of Matrigel (Sigma-Aldrich, MO, USA), diluted in phenol red and FBS-free DMEM at a final concentration of $2 \mathrm{mg} / \mathrm{mL}$, was added to the transwell inserts $(8.0 \mu \mathrm{m}$ membrane; Corning, USA) placed on six-well plates and incubated for 24 hours at $37^{\circ} \mathrm{C}$, under $95 \%$ humidity $/ 5 \% \mathrm{CO}_{2}$ atmosphere. $4 \times 10^{5}$ U87 cells and $3 \times 10^{5} \mathrm{U} 251$ cells cultured in phenol red and hormone-free DMEM medium were suspended in $1.5 \mathrm{~mL}$ of phenol red and FBS-free DMEM that included $100 \mathrm{ng} / \mathrm{mL}$ of recombinant PIBF and $10 \mu \mathrm{M}$ Ara-C. Cells were plated on the matrigel and phenol red-free DMEM medium supplemented with fetal bovine serum (10\%) with hormones was added to the bottom of the well as chemoattractant. The plate was incubated for $24 \mathrm{~h}$, then the matrigel was removed, and the cells were fixed with paraformaldehyde (4\%) and stained with crystal violet (1\%). Images of 5 random fields of each insert were captured with an Infinity 1-2C camera (Lumenera, ON, CAN) attached to an inverted microscope CKX41 (Olympus, TYO, JPN) at 40x magnification, and the number of invasive cells was counted using the ImageJ software (National Institute of Health, WA, USA).

2.10. Statistical Analysis. All data were analyzed and plotted using the GraphPad Prism 5.0 software (GraphPad Software, CA, USA). A one-way ANOVA was used for Western Blot 




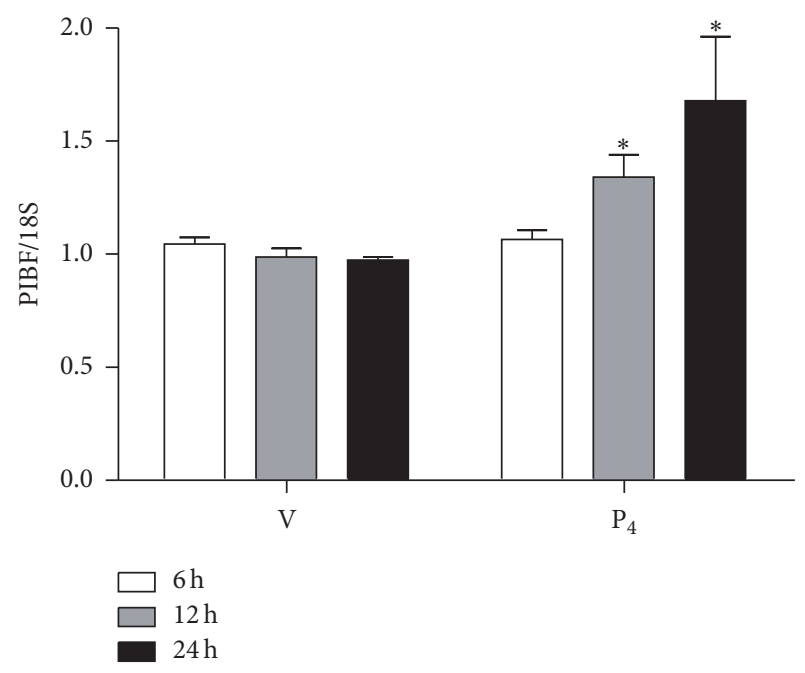

(b)

Figure 1: $\mathrm{P}_{4}$ regulates PIBF expression in glioblastoma cells. PIBF gene expression was evaluated by RT-PCR in U87 cells treated with vehicle (V, cyclodextrin $0.02 \%$ ) and $\mathrm{P}_{4}(10 \mathrm{nM}$ ) for 6, 12, and $24 \mathrm{~h}$. (a) Representative image of PIBF gene expression (530 bp) at different times of treatment and the respective expression control gene $18 \mathrm{~S}$ rRNA $(150 \mathrm{bp})$. (b) Densitometric analysis of three independent experiments; PIBF expression values were normalized to those of the control gene $18 \mathrm{~S}$ rRNA. The data are expressed as the mean \pm S.E.M. with $n=3 ;^{*} p<0.05$ versus vehicle.

experiments and a two-way ANOVA was used for cell counting and migration assays, followed by the Bonferroni post hoc test in all cases. Data from the RT-PCR, proliferation, and invasion assays were analyzed by a two-tail unpaired Student's $t$-test. A value of $p<0.05$ was considered statistically significant as stated in the figure legends.

\section{Results}

3.1. PIBF Gene Expression Is Regulated by $P_{4}$. To assess the $\mathrm{P}_{4}$ mediated regulation of PIBF in U87 human glioblastoma cell line, we performed RT-PCR using cells treated with vehicle (cyclodextrin $0.02 \%$ ) and $\mathrm{P}_{4}(10 \mathrm{nM})$ for 6,12 , and $24 \mathrm{~h}$. A specific fragment of $530 \mathrm{bp}$ was amplified in U87 cells. $\mathrm{P}_{4}$ treatment did not modify PIBF expression at $6 \mathrm{~h}$, but at 12 and $24 \mathrm{~h}$ it significantly increased its expression when compared to the vehicle (Figures 1(a) and 1(b)).

3.2. $P_{4}$ Upregulates PIBF $57 \mathrm{kDa}$ Isoform Content. Several PI$\mathrm{BF}$ isoforms are produced by alternative mRNA splicing and particularly the $90 \mathrm{kDa}$ isoform is frequently overexpressed in cancer cells $[9,10,18]$. We first evaluated if PIBF isoforms were expressed in U87 cells and also if their content was regulated by $\mathrm{P}_{4}$. We detected by Western Blot two main isoforms, the largest one of $90 \mathrm{kDa}$ and a shorter one of $57 \mathrm{kDa}$ (Figure 2). In U87 cells, the $90 \mathrm{kDa}$ isoform was the most abundant one. $\mathrm{P}_{4}$ treatment had no effects on PIBF isoforms content at $12 \mathrm{~h}$ (Figure 2(a)), while at $24 \mathrm{~h}$ we observed an increase in the content of the $57 \mathrm{kDa}$ isoform that was blocked by RU486 (Figure 2(b)), suggesting its regulation through PR. The silencing of both PIBF isoforms with siRNAs reduced the intensity of PIBF bands 70\%, corroborating the specificity of the bands recognized by the used antibody (Figure 2(c)).

3.3. Cell Number and Proliferation Are Increased by PIBF. PIBF (100 and $200 \mathrm{ng} / \mathrm{mL}$ ) increased the number of cells on days 4 (47 and 42\%, resp.) and 5 (36 and 31\%, resp.) (Figure 3(a)) as compared with vehicle. None of the treatments had any effect on cell viability (Figure 3(b)). A BrdU incorporation assay was utilized in order to investigate whether the increase in the number of U87 cells by PIBF was due to an augment in cell proliferation. The low PIBF concentration $(100 \mathrm{ng} / \mathrm{mL})$ was used in these experiments and administered during 4 days. PIBF treatment enhanced by $30 \%$ the BrdU incorporation in U87 cells (Figures 3(c) and $3(\mathrm{~d}))$.

3.4. PIBF Induces Cell Migration. To evaluate if PIBF modifies the migration capabilities of U87 and U251 cells, a woundhealing assay was performed. During the experiment, the DNA synthesis inhibitor Ara-C was used to discard that an increase in the number of migrating cells was due to cell proliferation. The treatments of PIBF (100 and $200 \mathrm{ng} / \mathrm{mL}$ ) were added for $48 \mathrm{~h}$, and the respective images of the migrating cells were taken at $0,3,6,12,24$, and $48 \mathrm{~h}$ (Figures 4(a) and 4(b)). PIBF (100 ng/mL) increased the number of U87 and U251 migrating cells from 12 to $48 \mathrm{~h}$ and at $24 \mathrm{~h}$, respectively. Interestingly, the highest concentration of PIBF (200 ng/mL) augmented the number of migrating U251 cells at $48 \mathrm{~h}$, without effects on U87 cells (Figures 4(a) and 4(b)).

3.5. PIBF Increases the Number of Invasive Cells. To evaluate the effect of PIBF on the invasion capability of U87 and 

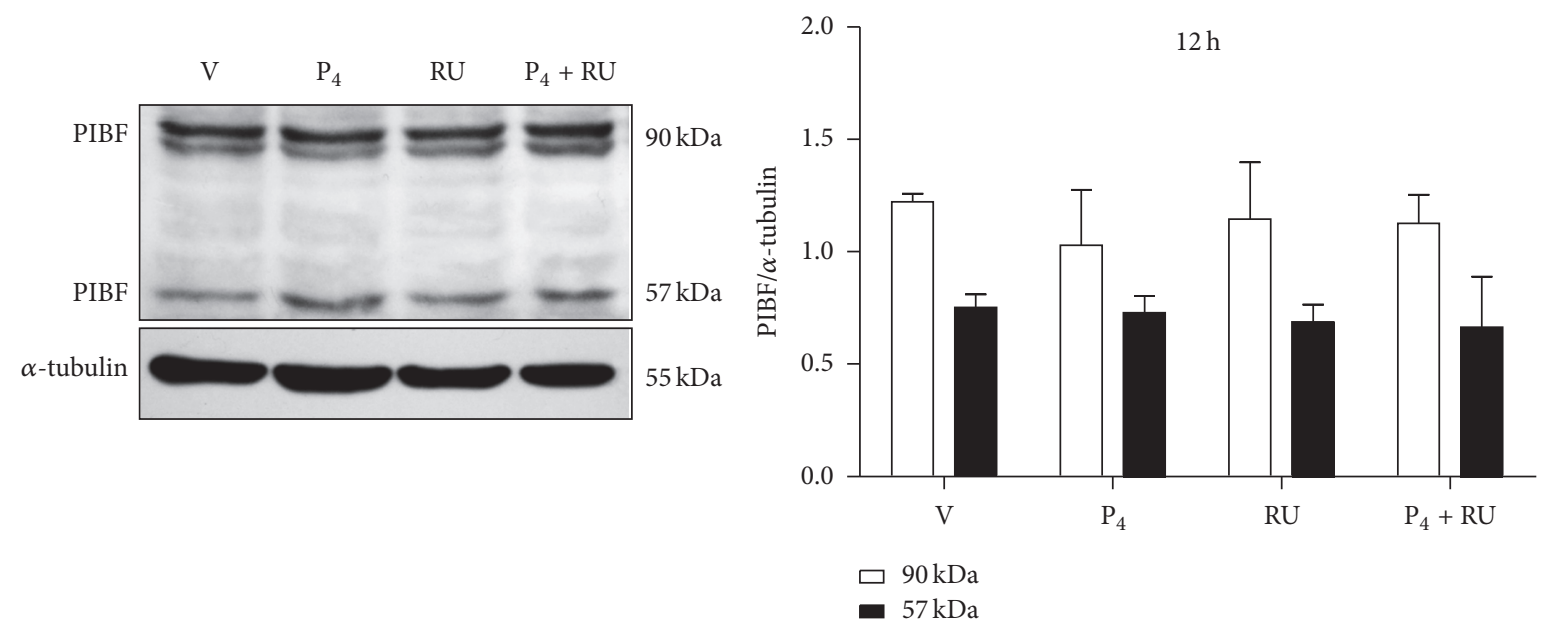

(a)
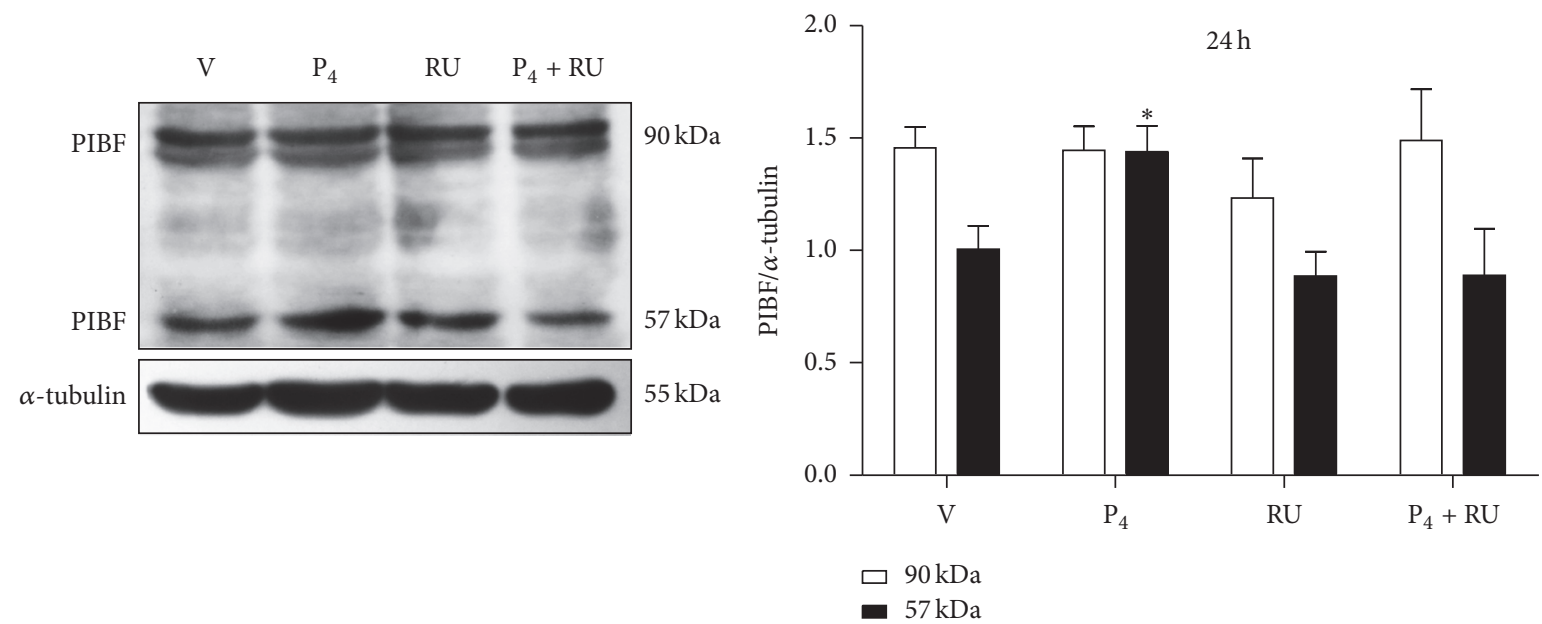

(b)

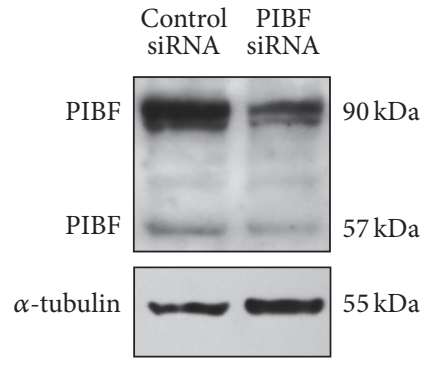

(c)

FIGURE 2: PIBF $(57 \mathrm{kDa})$ isoform is regulated by $\mathrm{P}_{4}$ in glioblastoma cells. Western Blot for PIBF protein was performed in U87 cells treated with vehicle (V, cyclodextrin $0.02 \%), \mathrm{P}_{4}(10 \mathrm{nM})$, RU486 $(10 \mu \mathrm{M})$, and $\mathrm{P}_{4}$ plus RU486 $\left(\mathrm{P}_{4}+\mathrm{RU}\right)$ for 12 and 24 h. Representative images of PIBF isoforms content are shown with their respective densitometric analysis after $12 \mathrm{~h}(\mathrm{a})$ and $24 \mathrm{~h}(\mathrm{~b})$ of treatment. For the densitometric analysis, PIBF values were corrected with those of the internal control, $\alpha$-tubulin. The data are expressed as the mean \pm S.E.M. with $n=4$; ${ }^{*} p<0.05$ versus the other treatment groups. (c) PIBF expression was silenced using a specific siRNA and a control siRNA that lacks any known mRNA target sequence. The image shows the reduction of both PIBF isoforms as evaluated by Western Blot.

U251 cells, we used the concentration of $100 \mathrm{ng} / \mathrm{mL}$ that induced an increase in cell migration in both cell lines at $24 \mathrm{~h}$. Transwell assays were performed with cells treated with PIBF for $24 \mathrm{~h}$; the medium was used as the vehicle. The images were captured from five random fields as it is shown in Figure 5(a). As in the case of migration, PIBF significantly increased the number of U87 (50\%) and U251 (30\%) invasive cells, in comparison with the vehicle (Figures 5(a) and $5(\mathrm{~b})$ ).

\section{Discussion}

Glioblastoma is the most common and aggressive brain tumor in humans; it has a high rate of mortality due to 


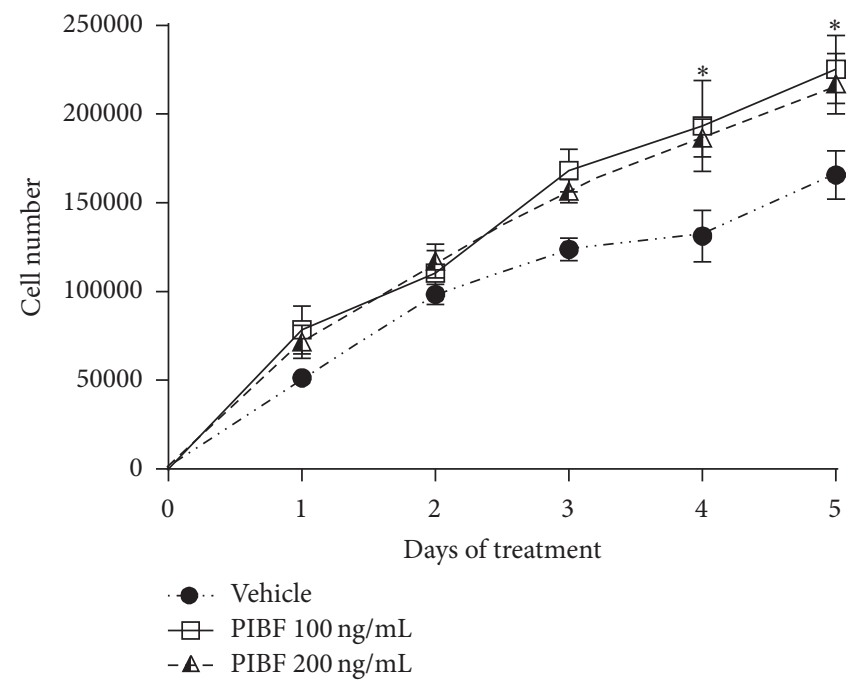

(a)
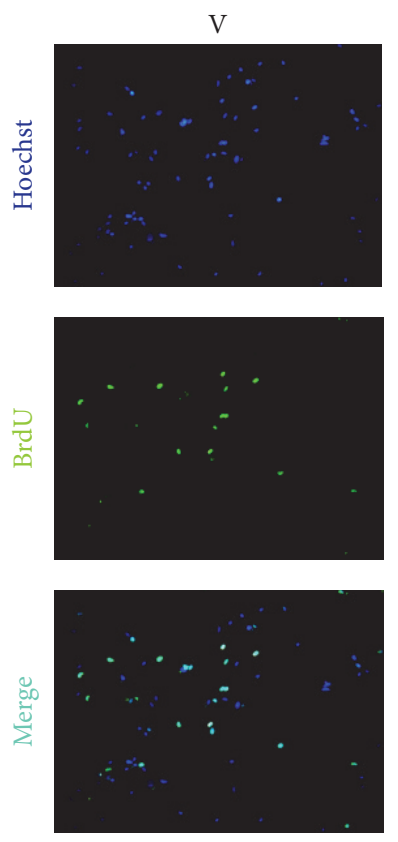

(c)


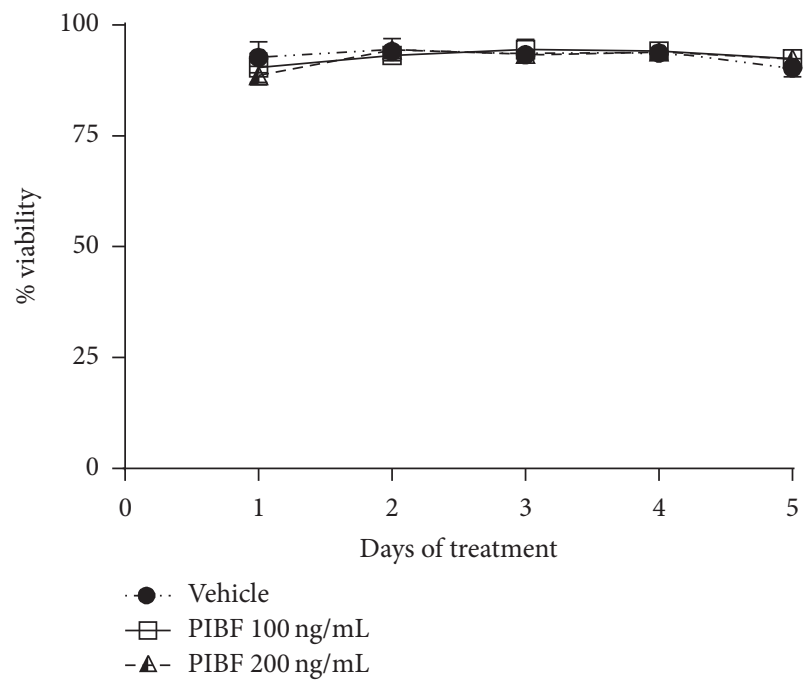

(b)

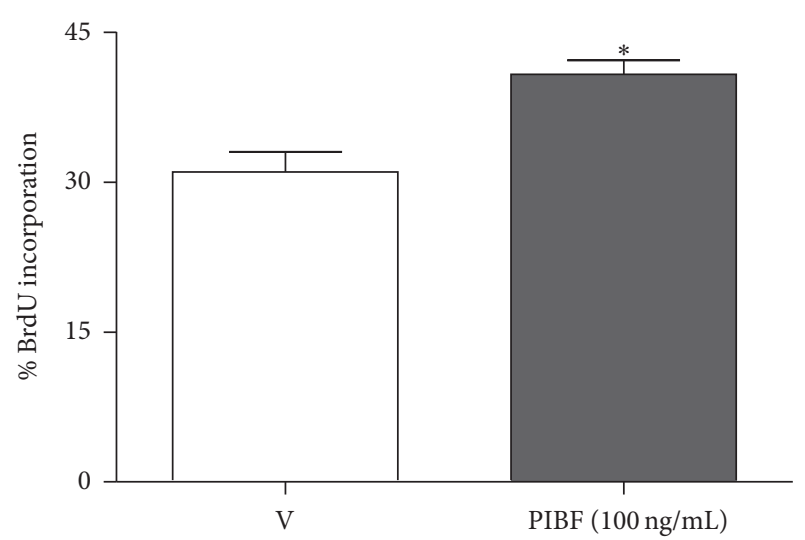

(d)

FIGURE 3: PIBF increases proliferation and the number of U87 cells. Cells were treated with recombinant PIBF (100 and $200 \mathrm{ng} / \mathrm{mL}) \mathrm{during} 5$ days, while the medium was used as the vehicle (V). Cells were harvested each day to determine the number of cells (a) and the cell viability (b) by using the trypan blue dye exclusion method. Cell proliferation was measured after the treatment of PIBF (100 ng/mL) during 4 days. Representative immunofluorescence images of cell nuclei (Hoechst stain, upper panel), BrdU positive cells (middle panel), and the merged image (lower panel) are shown (c). The graph shows the percentage of cells incorporating BrdU (d). The data were obtained from three independent experiments and are expressed as the mean \pm S.E.M. ${ }^{*} p<0.05$ versus vehicle.

its uncontrollable growth, its ability to infiltrate the adjacent tissue, and its short-term recurrence [24]. The current treatments neither improve the patient's life quality nor extend their survival time [31, 32]. Data from our laboratory have demonstrated that $\mathrm{P}_{4}$ induces both in vitro and in vivo glioblastoma cell proliferation and invasion partly through the activation of PR [4-6], but the mechanisms implicated in these effects are not well understood. There is evidence that very high concentrations of $\mathrm{P}_{4}$ (40 and $80 \mu \mathrm{M}$ ) alone or in combination with temozolomide (TMZ, 50 and $100 \mu \mathrm{M}$ ), the most used chemotherapeutic agent for glioma treatment, decrease the proliferation and migration in different cell lines derived from human glioblastomas, and this decrease was not blocked by RU486. However, in the same studies, lower concentrations $(0.1$ to $5 \mu \mathrm{M})$ of $\mathrm{P}_{4}$ increase cell viability/proliferation of human glioblastoma 

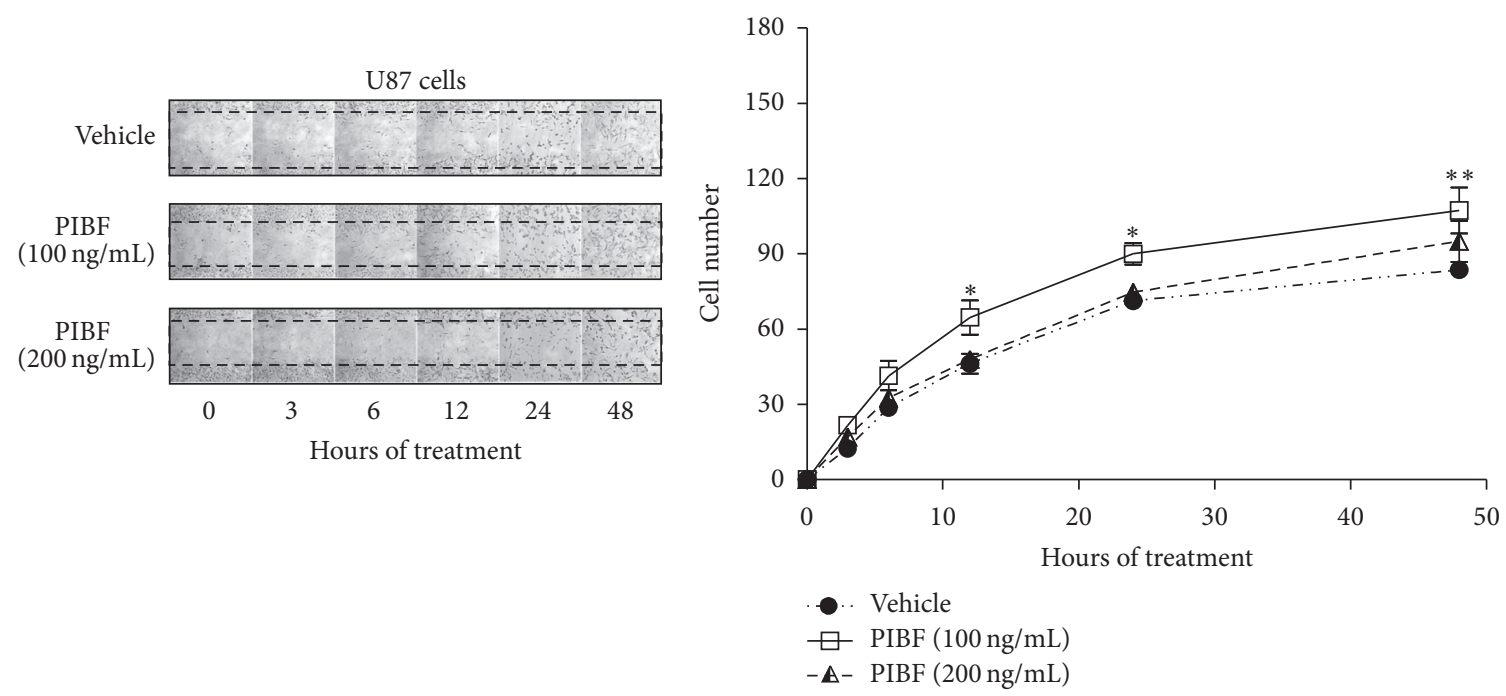

(a)
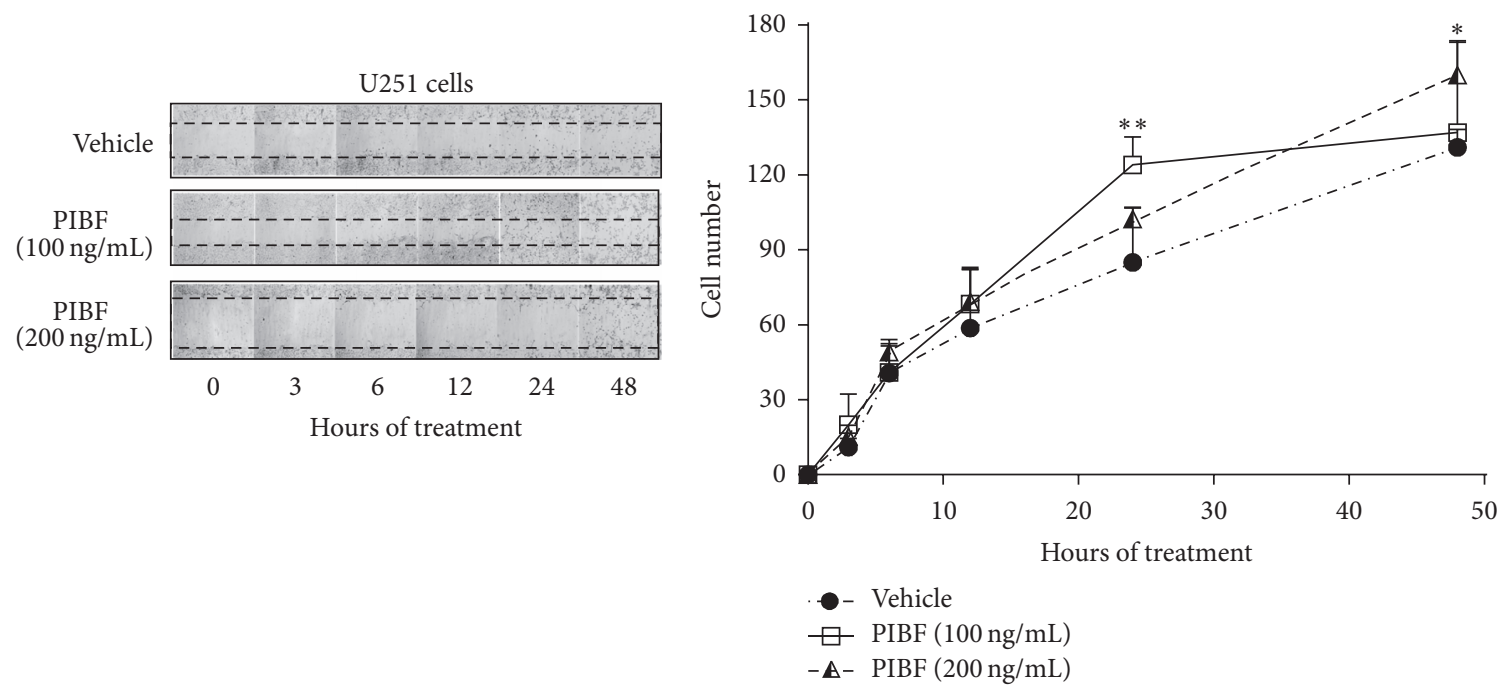

(b)

FIGURE 4: Migration of glioblastoma cells is enhanced by PIBF. Wound-healing assay was performed to evaluate the migration capabilities of U87 and U251 cells upon PIBF exposure. Cells were treated with the recombinant PIBF (100 and $200 \mathrm{ng} / \mathrm{mL}$ ) for $48 \mathrm{~h}$ while the medium was used as the vehicle (V). (a) and (b) show representative images of the wound areas taken at $0,3,6,12,24$, and $48 \mathrm{~h}$ after treatments in U87 and U251 cells, respectively, in the left panels. The graphs represent the number of cells that migrated into the wound area at the given time of treatment; the data were obtained from four independent experiments and are expressed as the mean \pm S.E.M.; ${ }^{*} p<0.01$ and ${ }^{* *} p<0.001$ versus vehicle.

cells through PR activation [33, 34], consistent with our previous reports. These differential effects could be due to the activation of distinct signaling mechanisms by $\mathrm{P}_{4}$, depending on its concentration. Further experiments with low and high concentrations of $\mathrm{P}_{4}$ and $\mathrm{PIBF}$, alone and with TMZ, are needed to elucidate this opposed effect.

There are reports that show an increase of PIBF serum concentration induced by $\mathrm{P}_{4}$ in both healthy women and those with different gynecological diseases [35]. In contrast, there is evidence indicating that, in MCF-7 breast cancer cells, $\mathrm{P}_{4}$ is not able to increase the expression of PIBF [9]. In this study, we demonstrated that $\mathrm{P}_{4}$ significantly increases PIBF gene expression at $12 \mathrm{~h}$ and this effect lasted for $24 \mathrm{~h}$.
Interestingly, $\mathrm{P}_{4}$ increases the expression of PIBF from $1 \mathrm{~h}$ to $24 \mathrm{~h}$ in U373 human astrocitoma cell line (now known as U251 glioblastoma cell line after a short tandem repeat-PCR genotyping) [10], indicating a differential hormone regulation of PIBF expression depending on cell context in human glioblastomas.

PIBF has several isoforms produced by alternative splicing $[9,36]$ but in tumor cells; these isoforms have not been fully characterized. In U87 cells we observed two isoforms: the $90 \mathrm{kDa}$ protein encoded by the full-length mRNA and a shorter isoform of $57 \mathrm{kDa}$, both found by González-Arenas et al. (2014) in astrocytoma cells as well [10]. The largest isoform is mainly localized in the nucleus, and it is associated with 

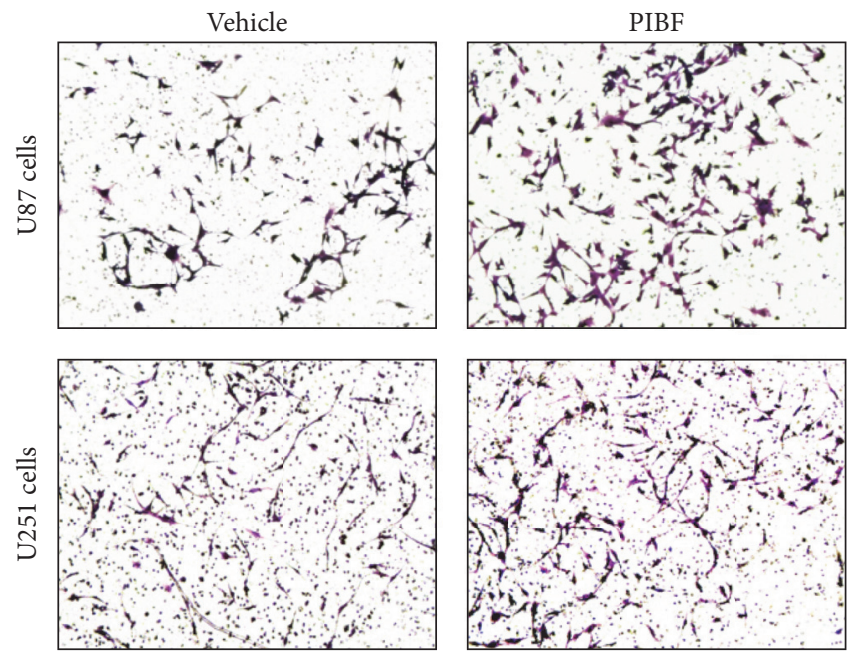

(a)
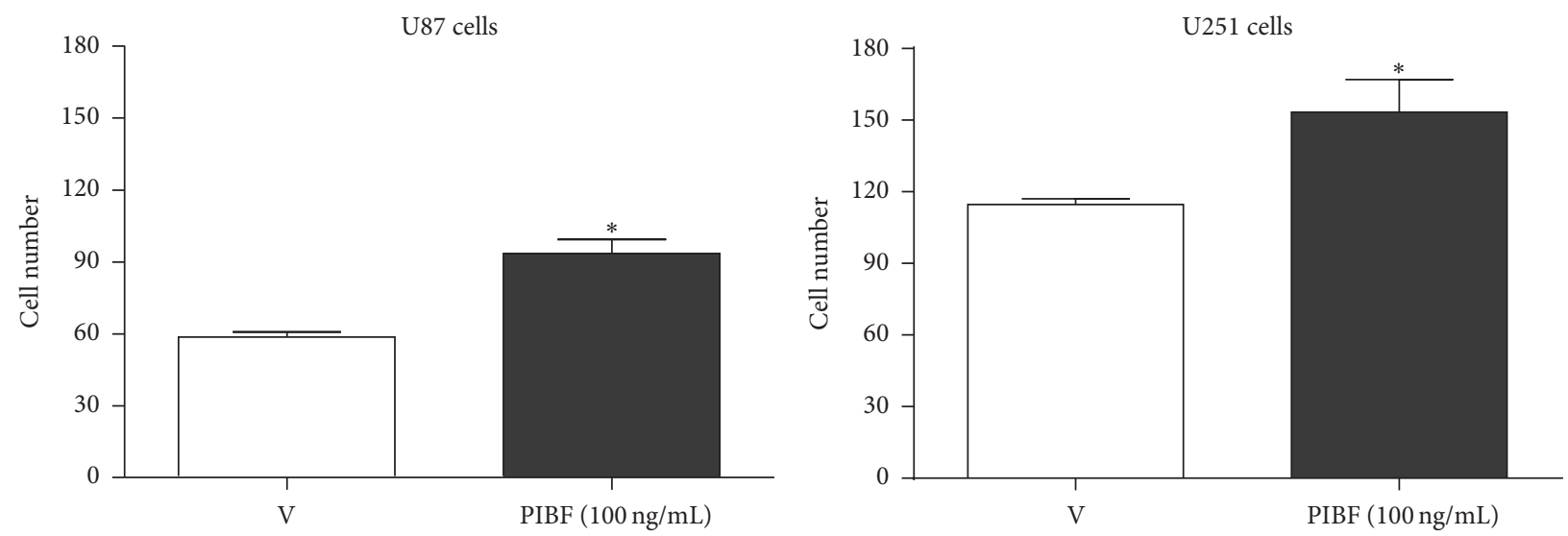

(b)

FIgURE 5: PIBF induces invasion of U87 and U251 cells. The number of invasive cells after PIBF treatment was evaluated by a transwell invasion assay. Cells were treated with recombinant PIBF $(100 \mathrm{ng} / \mathrm{mL})$ for $24 \mathrm{~h}$, while the medium was used as the vehicle. (a) Representative images of the invasive cells after PIBF treatment in both cell lines. (b) The graph shows the number of invasive cells from four independent experiments. The data are expressed as the mean \pm S.E.M.; ${ }^{*} p<0.01$ versus vehicle.

the centrosome, while the other shorter isoforms have been found in the intra- and extracellular compartments, and it is suggested they function in an autocrine mode $[9,10]$. In U87 cells we did not observe changes in the content of the fulllength PIBF protein upon treatment with $\mathrm{P}_{4}$, but it increased the $90 \mathrm{kDa}$ protein content in U373 cells (now known as U251) [10]. Remarkably, the content of $57 \mathrm{kDa}$ protein was upregulated at $24 \mathrm{~h}$ by $\mathrm{P}_{4}$ in U87 cells but not in U251 cells [10]. In both tumor cell lines the inducing effect of the hormone was blocked by the PR antagonist RU486, suggesting its regulation through PR. Further experiments are needed to evaluate the processes involved in this differential regulation of PIBF expression depending on the glioblastoma cell line.

PIBF expression has been described in several cells with a high proliferation rate $[9,17,37]$. It has been suggested that PIBF isoforms act as ligands implicated in the activation of proliferation signaling pathways including JAK1/STAT6 $[9,10,12,38]$, through the interaction with a receptor heterocomplex consisting of PIBF-R, which is attached to the plasma membrane by a glycosylphosphatidylinositol [13], and membrane receptor IL- $4 \mathrm{R} \alpha[10,12]$. In previous studies, PIBF $(200 \mathrm{ng} / \mathrm{mL})$ increased the number of astrocytoma cells through the activation of the IL-4R $\alpha /$ JAK1/STAT6 pathway [10]. In this work, we observed that PIBF induced cell proliferation, which was reflected in an increase in the number of U87 cells, probably by activating this same pathway.

The activation of JAK2/STAT3 pathway, which is overactivated in glioblastomas, promotes cell migration and invasion in several types of cancer [39, 40]. Interestingly, in the HT-1080 human fibrosarcoma cell line, it has been reported that PIBF is implicated in the augment of STAT3 phosphorylation [11]. In this study, we observed that PIBF $(100 \mathrm{ng} / \mathrm{mL})$ enhances the migration of glioblastoma cells at 12 and $24 \mathrm{~h}$ in U87 and U251 cells, respectively. Interestingly, chromatin immunoprecipitation assays in HT-1080 cells demonstrated that PIBF binds the promoter regions of IL-6 [11], an overexpressed cytokine in glioblastomas that acts as a ligand of the JAK2/STAT3 pathway [26, 41]. Therefore, 
the overactivation of this pathway by PIBF could be a possible mechanism underlying its effects on cell migration.

PIBF also binds the promoter region of epidermal growth factor (EGF) gene in human fibrosarcoma cells [11]. EGF through its receptor (EGFR), which is frequently overexpressed in glioblastomas [42], promotes the transcription of genes associated with the extracellular matrix proteolysis such as matrix metalloproteases 2 and 9 (MMP-2 and 9) [11]. In this study, we observed that the treatment of PIBF $(100 \mathrm{ng} / \mathrm{mL})$ augmented the invasive capability of both cell lines at $24 \mathrm{~h}$. Taking into consideration that PIBF acts as a transcriptional factor [11], we suggest a possible role of PIBF in regulating the expression of several target genes such as IL6 and EGF that could be associated with the invasive effects of glioblastoma cells. However, it is still unknown which of the PIBF isoforms promote the cell migration and invasion of glioblastoma cells.

\section{Conclusions}

In summary, our data suggest that $\mathrm{P}_{4}$ differentially upregulates PIBF expression by PR activation depending on the glioblastoma cell line and that PIBF increases glioblastoma cell proliferation, migration, and invasion, indicating an important role of this protein in the regulation of the mechanisms involved in tumor progression.

\section{Competing Interests}

The authors declare that they have no competing interests.

\section{Acknowledgments}

This work was supported by Consejo Nacional de Ciencia y Tecnología, Mexico, Grant no. 250866, and by Project PAPIIT IN201414, DGAPA, UNAM, Mexico.

\section{References}

[1] M. Schumacher, R. Guennoun, F. Robert et al., "Local synthesis and dual actions of progesterone in the nervous system: neuroprotection and myelination," Growth Hormone and IGF Research, vol. 14, pp. S18-S33, 2004.

[2] M. Rodriguez-Dorantes and I. Camacho-Arroyo, "Transcriptional activity regulated by progesterone receptor isoforms," Molecular Endocrinology, vol. 2006, no. 2, pp. 25-38, 2006.

[3] E. Cabrera-Muñoz, A. González-Arenas, M. Saqui-Salces et al., "Regulation of progesterone receptor isoforms content in human astrocytoma cell lines," Journal of Steroid Biochemistry and Molecular Biology, vol. 113, no. 1-2, pp. 80-84, 2009.

[4] A. G. Piña-Medina, V. Hansberg-Pastor, A. González-Arenas, M. Cerbón, and I. Camacho-Arroyo, "Progesterone promotes cell migration, invasion and cofilin activation in human astrocytoma cells," Steroids, vol. 105, pp. 19-25, 2016.

[5] L. Germán-Castelán, J. Manjarrez-Marmolejo, A. GonzálezArenas, M. G. González-Morán, and I. Camacho-Arroyo, "Progesterone induces the growth and infiltration of human astrocytoma cells implanted in the cerebral cortex of the rat,"
BioMed Research International, vol. 2014, Article ID 393174, 8 pages, 2014.

[6] G. González-Agüero, A. A. Gutiérrez, D. González-Espinosa et al., "Progesterone effects on cell growth of U373 and D54 human astrocytoma cell lines," Endocrine, vol. 32, no. 2, pp. 129-135, 2007.

[7] J. Szekeres-Bartho, B. Autran, P. Debre, G. Andreu, L. Denver, and G. Chaouat, "Immunoregulatory effects of a suppressor factor from healthy pregnant women's lymphocytes after progesterone induction," Cellular Immunology, vol. 122, no. 2, pp. 281-294, 1989.

[8] R. Druckmann and M.-A. Druckmann, "Progesterone and the immunology of pregnancy," Journal of Steroid Biochemistry and Molecular Biology, vol. 97, no. 5, pp. 389-396, 2005.

[9] M. Lachmann, D. Gelbmann, E. Kálmán et al., "PIBF (progesterone induced blocking factor) is overexpressed in highly proliferating cells and associated with the centrosome," International Journal of Cancer, vol. 112, no. 1, pp. 51-60, 2004.

[10] A. González-Arenas, P. Valadez-Cosmes, C. Jiménez-Arellano, M. López-Sánchez, and I. Camacho-Arroyo, "Progesteroneinduced blocking factor is hormonally regulated in human astrocytoma cells, and increases their growth through the IL4R/JAK1/STAT6 pathway," Journal of Steroid Biochemistry and Molecular Biology, vol. 144, pp. 463-470, 2014.

[11] M. Halasz, B. Polgar, G. Berta, L. Czimbalek, and J. SzekeresBartho, "Progesterone-induced blocking factor differentially regulates trophoblast and tumor invasion by altering matrix metalloproteinase activity," Cellular and Molecular Life Sciences, vol. 70, no. 23, pp. 4617-4630, 2013.

[12] N. Kozma, M. Halasz, B. Polgar et al., "Progesterone-induced blocking factor activates STAT6 via binding to a novel IL-4 receptor," The Journal of Immunology, vol. 176, no. 2, pp. 819826, 2006.

[13] C. de la Haba, J. R. Palacio, T. Palkovics, J. Szekeres-Barthó, A. Morros, and P. Martínez, "Oxidative stress effect on progesterone-induced blocking factor (PIBF) binding to PIBF-receptor in lymphocytes," Biochimica et Biophysica Acta (BBA)Biomembranes, vol. 1838, no. 1, pp. 148-157, 2014.

[14] J. Szekeres-Bartho and B. Polgar, "PIBF: the double edged sword. Pregnancy and tumor," American Journal of Reproductive Immunology, vol. 64, no. 2, pp. 77-86, 2010.

[15] J. Szekeres-Bartho, M. Halasz, and T. Palkovics, "Progesterone in pregnancy; receptor-ligand interaction and signaling pathways," Journal of Reproductive Immunology, vol. 83, no. 1-2, pp. 60-64, 2009.

[16] B. C. Merk, J. L. Owens, M.-B. S. Lopes, C. M. Silva, and I. M. Hussaini, "STAT6 expression in glioblastoma promotes invasive growth," BMC Cancer, vol. 11, article 184, 2011.

[17] C. Anderle, A. Hammer, B. Polgár et al., "Human trophoblast cells express the immunomodulator progesterone-induced blocking factor," Journal of Reproductive Immunology, vol. 79, no. 1, pp. 26-36, 2008.

[18] D. Kyurkchiev, E. Naydenov, K. Tumangelova-Yuzeir et al., "Cells isolated from human glioblastoma multiforme express progesterone-induced blocking factor (PIBF)," Cellular and Molecular Neurobiology, vol. 34, no. 4, pp. 479-489, 2014.

[19] J. H. Check, M. Sarumi, A. DiAntonio, K. Hunter, G. Simpkins, and M. Duroseau, "Serum levels of the progesterone induced blocking factor do not precipitously rise in women with gynecologic cancer in contrast to women exposed to progesterone," Clinical and Experimental Obstetrics and Gynecology, vol. 42, no. 5, pp. 563-567, 2015. 
[20] J. H. Check, A. Rosenberg, A. DiAntonio, H. Rui, R. Cohen, and G. DiAntonio, "Abstract 1281: serum levels of the immunomodulatory protein, the progesterone induced blocking factor (PIBF) are not higher in women with progesterone $(\mathrm{P})$ receptor (R) positive vs. negative breast cancer," Cancer Research, vol. 75, supplement 15, pp. 1281-1281, 2015.

[21] J. H. Check, M. P. Dougherty, G. DiAntonio, J. Vaniver, M. Duroseau, and M. D. Srivastava, "Abstract 1282: comparison of serum progesterone levels of the immunomodulatory protein, the progesterone induced blocking factor, in people with BRCA2 mutations associated with and not associated with a high risk of cancer," Cancer Research, vol. 75, no. 15, article 1282, 2015.

[22] V. Calvo and M. Beato, "BRCAl counteracts progesterone action by ubiquitination leading to progesterone receptor degradation and epigenetic silencing of target promoters," Cancer Research, vol. 71, no. 9, pp. 3422-3431, 2011.

[23] D. N. Louis, A. Perry, G. Reifenberger et al., "The 2016 world health organization classification of tumors of the central nervous system: a summary," Acta Neuropathologica, vol. 131, no. 6, pp. 803-820, 2016.

[24] F. B. Furnari, T. Fenton, R. M. Bachoo et al., "Malignant astrocytic glioma: genetics, biology, and paths to treatment," Genes and Development, vol. 21, no. 21, pp. 2683-2710, 2007.

[25] J. H. Check, C. Wilson, R. Cohen, and M. Sarumi, "Evidence that mifepristone, a progesterone receptor antagonist, can cross the blood brain barrier and provide palliative benefits for glioblastoma multiforme grade IV,' Anticancer Research, vol. 34, no. 5, pp. 2385-2388, 2014.

[26] A. Authier, K. J. Farrand, K. W. R. Broadley et al., "Enhanced immunosuppression by therapy-exposed glioblastoma multiforme tumor cells," International Journal of Cancer, vol. 136, no. 11, pp. 2566-2578, 2015.

[27] J. H. Check, P. Nazari, J. Goldberg, W. Yuen, and D. Angotti, “A model for potential tumor immunotherapy based on knowledge of immune mechanisms responsible for spontaneous abortion," Medical Hypotheses, vol. 57, no. 3, pp. 337-343, 2001.

[28] A. Waziri, "Glioblastoma-derived mechanisms of systemic immunosuppression," Neurosurgery Clinics of North America, vol. 21, no. 1, pp. 31-42, 2010.

[29] R. Raghupathy, E. Al-Mutawa, M. Al-Azemi, M. Makhseed, F. Azizieh, and J. Szekeres-Bartho, "Progesterone-induced blocking factor (PIBF) modulates cytokine production by lymphocytes from women with recurrent miscarriage or preterm delivery," Journal of Reproductive Immunology, vol. 80, no. 1-2, pp. 91-99, 2009.

[30] J. H. Check, E. Dix, and L. Sansoucie, "Support for the hypothesis that successful immunotherapy of various cancers can be achieved by inhibiting a progesterone associated immunomodulatory protein," Medical Hypotheses, vol. 72, no. 1, pp. 87-90, 2009.

[31] L. Cheng, S. Bao, and J. N. Rich, "Potential therapeutic implications of cancer stem cells in glioblastoma," Biochemical Pharmacology, vol. 80, no. 5, pp. 654-665, 2010.

[32] M. J. Riemenschneider and G. Reifenberger, "Astrocytic tumors," Recent Results in Cancer Research, vol. 171, pp. 3-24, 2009.

[33] F. Atif, S. Yousuf, and D. G. Stein, "Anti-tumor effects of progesterone in human glioblastoma multiforme: role of PI3K/Akt/ mTOR signaling," Journal of Steroid Biochemistry and Molecular Biology, vol. 146, pp. 62-73, 2015.

[34] F. Atif, N. R. Patel, S. Yousuf, and D. G. Stein, “The synergistic effect of combination progesterone and temozolomide on human glioblastoma cells," PLoS ONE, vol. 10, no. 6, Article ID e0131441, 2015.

[35] R. A. Cohen, J. H. Check, and M. P. Dougherty, "Evidence that exposure to progesterone alone is a sufficient stimulus to cause a precipitous rise in the immunomodulatory protein the progesterone induced blocking factor (PIBF)," Journal of Assisted Reproduction and Genetics, vol. 33, no. 2, pp. 221-229, 2016.

[36] A. Bogdan, B. Polgar, and J. Szekeres-Bartho, "Progesterone induced blocking factor isoforms in normal and failed murine pregnancies," American Journal of Reproductive Immunology, vol. 71, no. 2, pp. 131-136, 2014.

[37] M. D. Srivastava, A. Thomas, B. I. S. Srivastava, and J. H. Check, "Expression and modulation of progesterone induced blocking factor (PIBF) and innate immune factors in human leukemia cell lines by progesterone and mifepristone," Leukemia and Lymphoma, vol. 48, no. 8, pp. 1610-1617, 2007.

[38] N. Kozma, M. Halasz, T. Palkovics, and J. Szekeres-Bartho, “The progesterone-induced blocking factor modulates the balance of PKC and intracellular $\mathrm{Ca}^{++}$, American Journal of Reproductive Immunology, vol. 55, no. 2, pp. 122-129, 2006.

[39] C. Senft, M. Priester, M. Polacin et al., "Inhibition of the JAK-2/STAT3 signaling pathway impedes the migratory and invasive potential of human glioblastoma cells," Journal of Neuro-Oncology, vol. 101, no. 3, pp. 393-403, 2011.

[40] M. Priester, E. Copanaki, V. Vafaizadeh et al., "STAT3 silencing inhibits glioma single cell infiltration and tumor growth," Neuro-Oncology, vol. 15, no. 7, pp. 840-852, 2013.

[41] A. Canellada, I. Alvarez, L. Berod, and T. Gentile, "Estrogen and progesterone regulate the IL- 6 signal transduction pathway in antibody secreting cells," Journal of Steroid Biochemistry and Molecular Biology, vol. 111, no. 3-5, pp. 255-261, 2008.

[42] A. H. Thorne, C. Zanca, and F. Furnari, "Epidermal growth factor receptor targeting and challenges in glioblastoma," NeuroOncology, vol. 18, no. 7, pp. 914-918, 2016. 


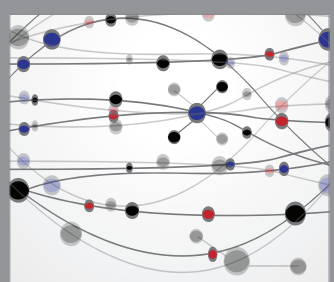

The Scientific World Journal
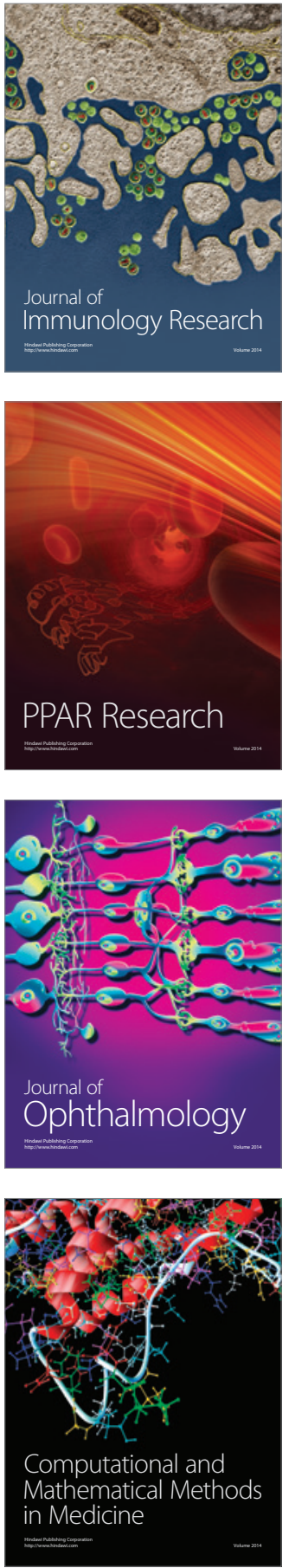

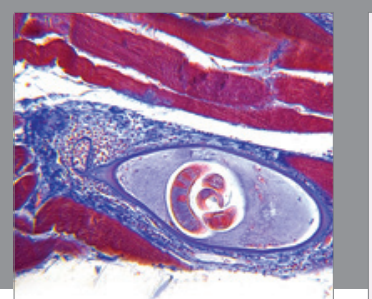

Gastroenterology Research and Practice
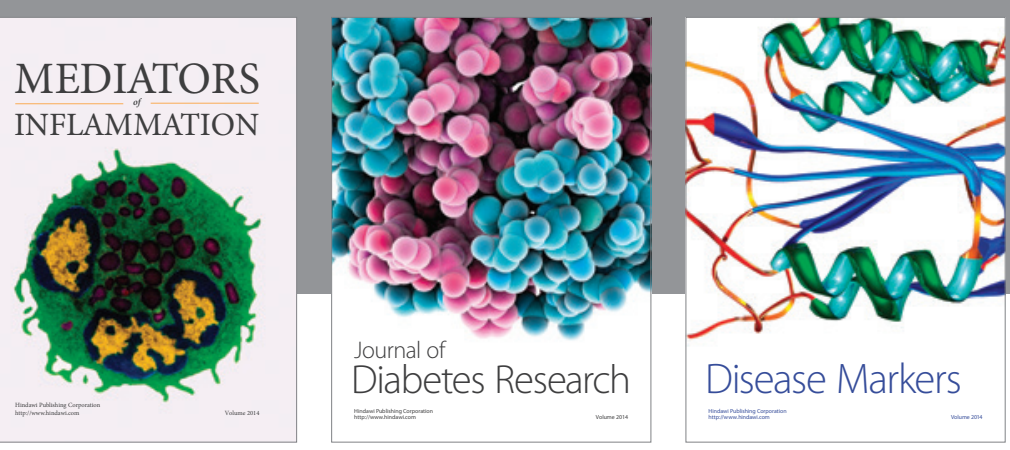

Disease Markers

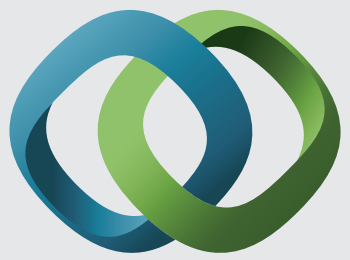

\section{Hindawi}

Submit your manuscripts at

https://www.hindawi.com
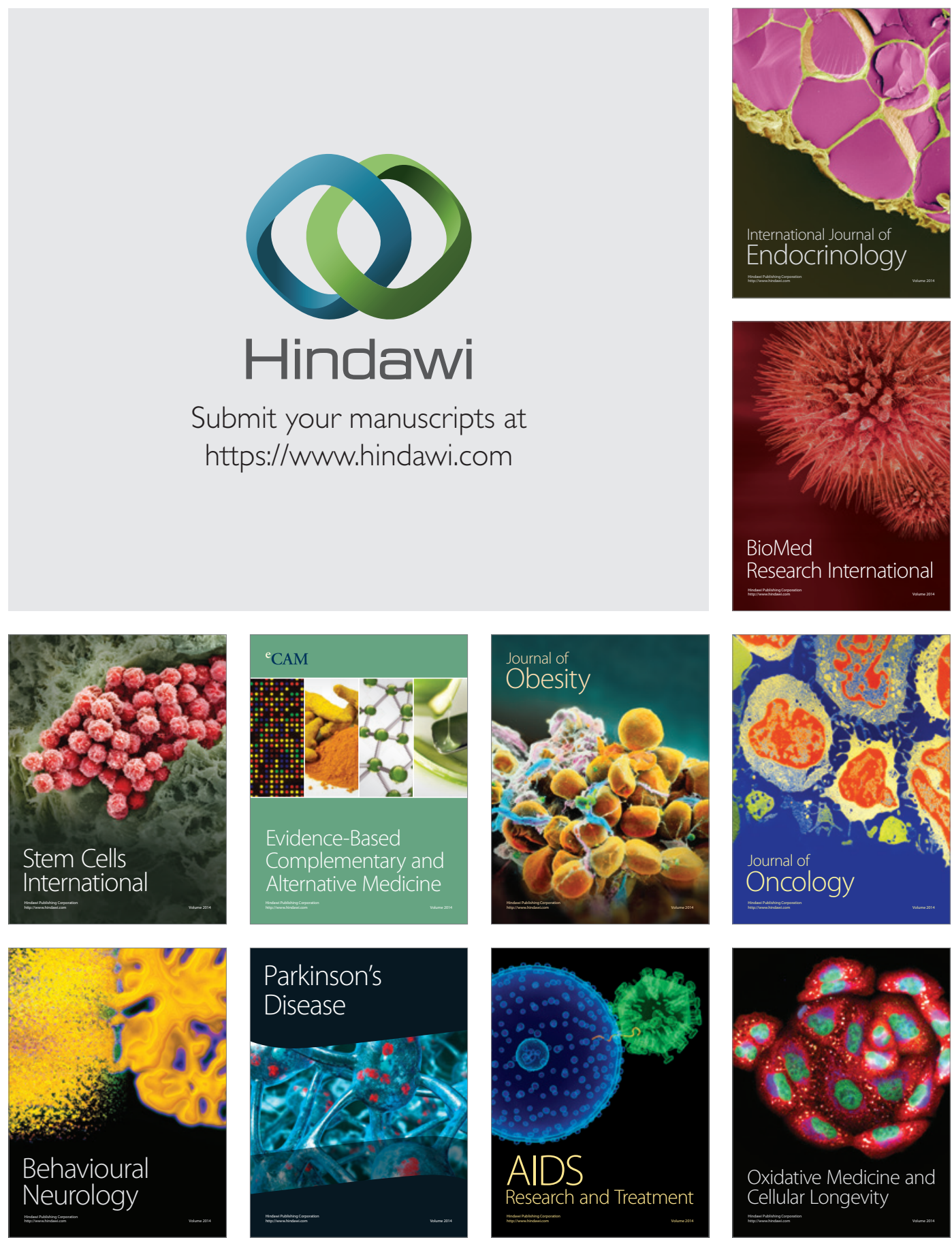